\section{Grafting Affects Growth, Yield, Nutrient Uptake, and Partitioning Under Cadmium Stress in Tomato}

\author{
Pradeep Kumar \\ ICAR-Central Arid Zone Research Institute, 342003 Jodhpur, Rajasthan, India; \\ and Department of Agriculture, Forestry, Nature and Energy, University of \\ Tuscia, 01100 Viterbo, Italy
}

\section{Menahem Edelstein \\ Newe Ya'ar Research Center, ARO, Ramat Yishay 30095, Israel}

\author{
Mariateresa Cardarelli \\ Consiglio per la Ricerca in Agricoltura e l'analisi dell'economia agraria, Centro \\ di ricerca per lo studio delle Relazioni tra Pianta e Suolo, 00184 Roma, Italy
}

Emanuela Ferri and Giuseppe Colla ${ }^{1}$

Department of Agriculture, Forestry, Nature and Energy, University of Tuscia, 01100 Viterbo, Italy

Additional index words. yield, cadmium toxicity, rootstocks/Solanum lycopersicum

\begin{abstract}
A greenhouse experiment was conducted to determine the influence of long-term cadmium (Cd) exposure $(0,25$, or $50 \mu \mathrm{M}$ of $\mathrm{Cd}$ ) on crop productivity, fruit quality, leaf chlorophyll content, fluorescence, and mineral composition in plants of tomato (Solanum lycopersicum L. cv. Ikram), either nongrafted, self-grafted, or grafted onto rootstocks of tomato (Maxifort or Unifort) and eggplant (Black Beauty). Both moderate (25 $\mu \mathrm{M})$ and high $(50 \mu \mathrm{M})$ concentration of $\mathrm{Cd}$ in root environment considerably decreased the fruit yield and fruit number in response to $\mathrm{Cd}$ levels, whereas mean fruit weight decreased but was similar to both Cd supply levels. The fruit yield, shoot and root biomass, and leaf area (LA) were higher in plants grafted onto tomato rootstocks and especially onto Maxifort in comparison with nongrafted or self-grafted plants and especially grafted onto Black Beauty. The higher plant performance of tomato rootstock-grafted plants were related to higher chlorophyll fluorescence and photosynthetic pigments concentration in leaves associated with better nutrient translocation and availability (higher $\mathrm{Ca}, \mathrm{Mg}, \mathrm{Fe}, \mathrm{Mn}$, and $\mathrm{Cu}$ ) in leaves. The content of $\mathrm{Cd}$ was also lower in leaves and fruits of Maxifort-grafted plants. Concerning fruit quality, especially peel color, toxicity symptoms, and Cd concentration, Black Beauty followed by Maxifort-grafted plants were better than the other grafting combinations. However, plants grafted onto Black Beauty rootstock resulted in lowest fruit yield and plant growth attributes due to lower nutrient uptake and translocation indicating some incompatibility reaction between Black Beauty rootstock and Ikram scion.
\end{abstract}

The growing concerns over heavy metal pollution of soil and water in the current era of industrialization have received increasing attention of researchers worldwide as its consequences can potentially endanger plant and human health. In particular, $\mathrm{Cd}$ is one of the most dangerous metals in agricultural soils (Dong et al., 2007). Cd concentration above $3 \mu \mathrm{g} \cdot \mathrm{g}^{-1}$ in agriculture soil is considered to be unsafe for crop production (Lux et al., 2011). It is suggested that $\mathrm{Cd}$ can cause

Received for publication 24 June 2015. Accepted for publication 7 Oct. 2015 .

Indian Council of Agricultural Research, New Delhi, is acknowledged for providing ICAR-International fellowship to Pradeep Kumar to perform research at Tuscia University, Viterbo, Italy. This work is part of the Pradeep Kumar's PhD program in Horticulture at the Department DAFNE of Tuscia University, Viterbo, Italy.

${ }^{1}$ Corresponding author. E-mail: giucolla@unitus.it.
In recent years, concerted efforts focused on reducing heavy metals uptake and accumulation in the aerial plant organs. Development of cultivars able to limit uptake and translocation of heavy metals represents a constituent part of environmentally friendly technologies, which allow harvesting clean agricultural products on polluted soil (Alybayeva et al., 2014). However, it is too long process and takes years to breed a variety of desired traits. Moreover, it is still not clear whether plant's $\mathrm{Cd}$ tolerance and hyperaccumulation abilities are genetically independent or related traits (Tsyganov et al., 2007).

One of the possible sustainable strategies for improving plant tolerance to Cd stress, particularly in fruit vegetables, would be by grafting them onto resistant/tolerant rootstocks. Grafting has been primarily used in fruiting vegetables to improve plant tolerance against some soilborne pathogens (Crinò et al., 2007; Lee, 1994) but its application dramatically increased over the years in mitigating the negative effects of other biotic and abiotic stresses with expanding the reasons of grafting. In recent past, grafting has emerged as useful tool to increase plant vigor and yield (Colla et al., 2008), induce higher tolerance to abiotic stress conditions such as salinity, alkalinity (Colla et al., 2010a, 2010b, 2012, 2013), heavy metal, (Kumar et al., 2015; Rouphael et al., 2008b; Savvas et al., 2013), thermal stress (Schwarz et al., 2010), water stress (Rouphael et al., 2008a), and improve fruit quality (Rouphael et al., 2010, 2012).

To our knowledge, few studies are reporting the effectiveness of grafting in reducing fruit and/or shoot $\mathrm{Cd}$ contents in vegetables (Arao et al., 2008; Mori et al., 2009; Savvas et al., 2013). A substantial reduction of fruit and shoot Cd content in eggplant (Solanum melongena $\mathrm{L}$.) was achieved by grafting onto Solanum torvum rootstock (Arao et al., 2008). The reduced fruit and shoot Cd content was mainly due restricted root-to-shoot Cd transfer by $S$. torvum rootstock, as also revealed by the study of Mori et al. (2009). Similarly, Savvas et al. (2013) were able to effectively reduce fruit $\mathrm{Cd}$ content in cucumber (Cucumis sativus L.) by grafting onto a commercial interspecific hybrid Cucurbita rootstock, 'Power' (Cucurbita maxima Duch. $\times$ Cucurbita moschata Duch.), where the reduced fruit $\mathrm{Cd}$ content was mainly due to limited $\mathrm{Cd}$ uptake by the roots apparatus. However, no information is available up-todate regarding the impact of grafting and rootstock genotype on the uptake and accumulation of $\mathrm{Cd}$ in tomato, which is one of the world's most important vegetables, grown in both the open field and greenhouse conditions.

Starting from the above consideration, the present study aimed at evaluating the performance of tomato (Solanum lycopersicum L. cv. Ikram), either nongrafted or grafted onto its own roots (self-grafted) or onto selected rootstocks of tomato and eggplant under longterm $\mathrm{Cd}$ exposure $(0,25$, and $50 \mu \mathrm{M}$ of $\mathrm{Cd})$. 
The relative performance of different grafting combinations under $\mathrm{Cd}$ stress was determined in terms of plant growth, fruit yield and quality, SPAD index and chlorophyll fluorescence, chlorophyll and carotenoid content, and mineral element composition and partitioning in different plant organs.

\section{Materials and Methods}

Plant material and growing conditions. Tomato (S. lycopersicum L.) cv. Ikram (Syngenta, Milan, Italy), a leading cluster-bearing cultivar in Italy and other Mediterranean countries, was selected as scion. Scion cv. Ikram either self-grafted or grafted onto tomato or eggplant rootstocks, whereas nongrafted Ikram was used as a control plant. Plants were grown during autumn growing season over the period from 4 Aug. to 18 Dec. 2012 (136 d after transplanting) in a heated greenhouse located at the Experimental Farm of Tuscia University, Italy (lat. $42^{\circ} 25^{\prime} \mathrm{N}$, long. $12^{\circ} 08^{\prime} \mathrm{E}$, alt. $310 \mathrm{~m}$ above sea level). The greenhouse was maintained at daily temperature between 18 and $33{ }^{\circ} \mathrm{C}$, and day/night relative humidity of $55 / 85 \%$. The selected tomato rootstocks were Maxifort and Unifort (De Ruiter/Monsanto, Bergschenhoek, The Netherlands), where Maxifort provides higher plant vigor than the Unifort. However, the eggplant (S. melongena L.) Heirloom cv. Black Beauty was included based on its earlier shown capability as rootstock for tomato in alleviating adverse effects of certain abiotic stresses in grafted tomato plants (Abdelmageed and Gruda, 2009).

Seedlings were produced by a commercial company (Centro SEIA, Sicilia, Italy) using the slant-cut (splice) graft technique. Tomato seedlings of good health at three to four trueleaf stage were transferred into pots $(6 \mathrm{~L})$ containing quartziferous sand. Pots were arranged in double rows providing the space between plants within a row $0.45 \mathrm{~m}$ and the distance between the centers of double rows $1.2 \mathrm{~m}$, giving a plant density of 3.7 plants $/ \mathrm{m}^{2}$. Pollination was facilitated by the bumble bees. Plants were grown as vertical cordons where all lateral branches were pruned and later the terminal bud was removed after having sixth fruit cluster.

Plants were subjected to three $\mathrm{Cd}$ concentrations namely 0,25 , and $50 \mu \mathrm{M}$ by adding appropriate amount of $\mathrm{CdCl}_{2}$ to the basic nutrient solution. The $\mathrm{Cd}$ treatment was initialized $27 \mathrm{~d}$ after the transplanting and continued until final crop harvest. The Cd concentration and duration of exposure decided as per the previous studies (Bertoli et al., 2012; Hediji et al., 2010). The basic (control) nutrient solution used in this experiment was a modified Hoagland and Arnon formulation, which was in the beginning applied at half concentration for 3 weeks and later shifted to full concentration (Jones, 1983). A composition of the basic nutrient solution, using salts of analytical grade, was $14.0 \mathrm{~mm} \mathrm{~N}-\mathrm{NO}_{3}$, $1.6 \mathrm{~mm} \mathrm{~S}, 1.5 \mathrm{~mm} \mathrm{P}, 6.0 \mathrm{~mm} \mathrm{~K}, 4.5 \mathrm{~mm} \mathrm{Ca}$, $1.5 \mathrm{~mm} \mathrm{Mg}, 20 \mu \mathrm{M} \mathrm{Fe}, 9 \mu \mathrm{M} \mathrm{Mn}, 0.3 \mu \mathrm{M} \mathrm{Cu}$, $1.6 \mu_{\mathrm{M} \mathrm{Zn}}, 20 \mu_{\mathrm{M}} \mathrm{B}$, and $0.3 \mu_{\mathrm{M}} \mathrm{Mo}$.
Deionized water was used for the preparation of all nutrient solutions. Nutrient solution, with or without $\mathrm{Cd}$, was pumped from independent supply tanks of $478 \mathrm{~L}$ through a drip irrigation system, with one emitter per plant of $2 \mathrm{~L} \cdot \mathrm{h}^{-1}$ flow rate. Five to 15 fertigations were applied per day, each of 2-5 min duration. Timing of the irrigations was increased to have at least $30 \%$ of the nutrient solution draining out from the pots (Rouphael et al., 2004, 2008c). The nutrient solutions were changed at every 10 - to $12-d$ intervals (in the beginning) to 5-6 d (full-grown plants stage). The $\mathrm{pH}$ of the nutrient solutions was adjusted to $5.6-5.8$ by adding proper amounts of $1 \mathrm{~N} \mathrm{HNO}_{3}$ stock solution.

The three nutrient solution treatments (nonCd control, 25, and $50 \mu \mathrm{M} \mathrm{Cd}$ ) were combined with the five grafting treatments (nongrafted Ikram, Ikram/Ikram, Ikram/Black Beauty, Ikram/Maxifort, or Ikram/Unifort), arranged in a randomized complete block design. Each treatment was replicated three times with three plants per plot.

Fruit and plant biomass production. Fully ripe fruit harvest was started on 26 Oct. and continued until the end of the experiment (18 Dec.). The fruit yield, number of fruits, and mean fruit weight were recorded for all individual plant. At the end of the experiment (136 d after transplanting, $18 \mathrm{Dec}$.), each plant was separated into different plant organs (stem, leaf, and root) and were dried in a forced-air oven at $80^{\circ} \mathrm{C}$ until constant weight for biomass determination. Shoot biomass was equal to the sum of aerial vegetative plant parts (leaves + stems). Leaf area was measured with an electronic area meter (Delta-T Devices Ltd., Cambridge, UK). At the termination of the experiment, stem girth of scion and rootstock were also measured above and below the graft union point, respectively.

Fruit quality analysis. At peak harvesting period, nine full red ripe fruits were selected per plot (three from each plant) to determine the fruit quality. Fruit firmness $\left(\mathrm{N} \cdot \mathrm{cm}^{-2}\right)$, by using a penetrometer (Bertuzzi FT 011; Milan, Italy), fitted with an 8-mm-diameter roundhead probe and fruit shape index (SI), the ratio of width to length were determined for each fruit. Total soluble solids (TSS, Brix) content of the fruit juice was determined by an Atago N1 refractometer (Atago Co. Ltd., Tokyo, Japan) and titratable acidity (TA) was determined by potentiometric titration with $0.1 \mathrm{M}$ $\mathrm{NaOH}$ up to $\mathrm{pH} 8.1$ and the results were expressed as percentage of citric acid in the juice. Fruit juice $\mathrm{pH}$ was also measured with a pH meter (HI-9023; Hanna Instruments, Padova, Italy). Fruits were dried in a forcedair oven at $80{ }^{\circ} \mathrm{C}$ until constant weight and weighed to determine the fruit dry matter (DM).

Fruit color measurements were performed on the surface of the tomatoes, around the equatorial region. The color was measured for 10 tomatoes per plot with four times for each tomato. A Minolta Chroma Meter CR200 (Minolta Camera Co. Ltd., Osaka, Japan) tristimulus color analyzer, consisting of a head with an 8-mm-diameter measuring area a diffuse illumination $/ 0^{\circ}$ viewing, was used.
Readings were reported in the $\mathrm{L}^{*}, \mathrm{a}^{*}$, and $\mathrm{b}^{*}$ system (Fanasca et al., 2006).

Chlorophyll fluorescence measurements. The Photosystem II (PSII) efficiency of leaves, estimated by the variable to maximum chlorophyll fluorescence ratio $\left(\mathrm{F}_{\mathrm{v}} / \mathrm{F}_{\mathrm{m}}\right)$ was measured by chlorophyll fluorometer Handy PEA (Hansatech Instruments Ltd, Norfolk, UK) as described by Colla et al. (2013). The measurement was done on the adaxial surface of six random leaves (in third-fourth leaflets from the top) per plot after at least 20-min dark adaptation. The maximum quantum yield of open PSII $\left(\mathrm{F}_{\mathrm{v}} / \mathrm{F}_{\mathrm{m}}\right)$ was calculated as $\left(\mathrm{F}_{\mathrm{m}}-\mathrm{F}_{0}\right) /$ $F_{m}$ (Maxwell and Johnson, 2000). The SPAD and fluorescence measurements were done at $90 \mathrm{~d}$ after the initiation of $\mathrm{Cd}$ treatment.

Leaf pigment determination. The leaf pigments (total chlorophyll and carotenoids) were extracted by homogenization of fresh leaf tissues $(0.5 \mathrm{~g})$ in acetone $(80 \%)$. The resulting extracts were centrifuged at $4800 g_{\mathrm{n}}$ for $20 \mathrm{~min}$. The total chlorophyll and carotenoid contents were determined by taking absorbance of the supernatant at 470,647 , and $664 \mathrm{~nm}$ by an ultraviolet-visible spectrophotometer (Perkin Elmer Inc., Norwalk, CT). The chlorophyll and carotenoid contents were calculated as were described by Lichtenhaler and Wellburn (1983) and the content was expressed on a fresh weight basis ( $\left.\mathrm{mg} \cdot \mathrm{g}^{-1}\right)$.

Analysis of $\mathrm{Cd}$ and mineral nutrient concentrations. The leaf, stem, fruit, and root tissues were ground separately in a Wiley mill to pass through a 20 -mesh screen. Then, $0.5 \mathrm{~g}$ of the dried plant tissues were analyzed for the following macro and micronutrients and toxic element: $\mathrm{N}, \mathrm{P}, \mathrm{K}, \mathrm{Ca}, \mathrm{Mg}, \mathrm{Fe}, \mathrm{Mn}$, $\mathrm{Zn}, \mathrm{Cu}, \mathrm{B}$, and $\mathrm{Cd}$. Nitrogen concentration in the plant tissues was determined after mineralization with sulfuric acid by "Kjeldahl method" (Bremner, 1965), instead of, P, K, $\mathrm{Ca}, \mathrm{Mg}, \mathrm{Fe}, \mathrm{Mn}, \mathrm{Zn}, \mathrm{Cu}, \mathrm{B}$, and Cd concentrations were determined by dry ashing at $400{ }^{\circ} \mathrm{C}$ for $24 \mathrm{~h}$, dissolving the ash in 1:20 $\mathrm{HNO}_{3}$, and assaying the solution obtained using an inductively coupled plasma emission spectrophotometer (ICP Iris; Thermo Optek, Milano, Italy) (Karla, 1998).

Statistical analysis. All data were statistically analyzed by analysis of variance using the SPSS software package (SPSS 10 for Windows, 2001). Duncan's multiple range test was performed at $P=0.05$ on each of the significant variables measured.

\section{Results}

Visual toxicity symptoms. Leaf chlorosis was observed only on older leaves especially in Ikram/Black Beauty grafting combination or nongrafted tomato plants, under severe Cd stress condition $(50 \mu \mathrm{M} C d$ ) (data not shown). The symptoms of $\mathrm{Cd}$ toxicity were also observed on fruits as stem-end yellowing, originating from fruit-stem attachment point, more pronounced under severe $\mathrm{Cd}$ stress (Fig. 1). The symptom was more pronounced in fruits of nongrafted plants followed by Ikram/Unifort and self-grafted plants, whereas the symptom was scarcely 

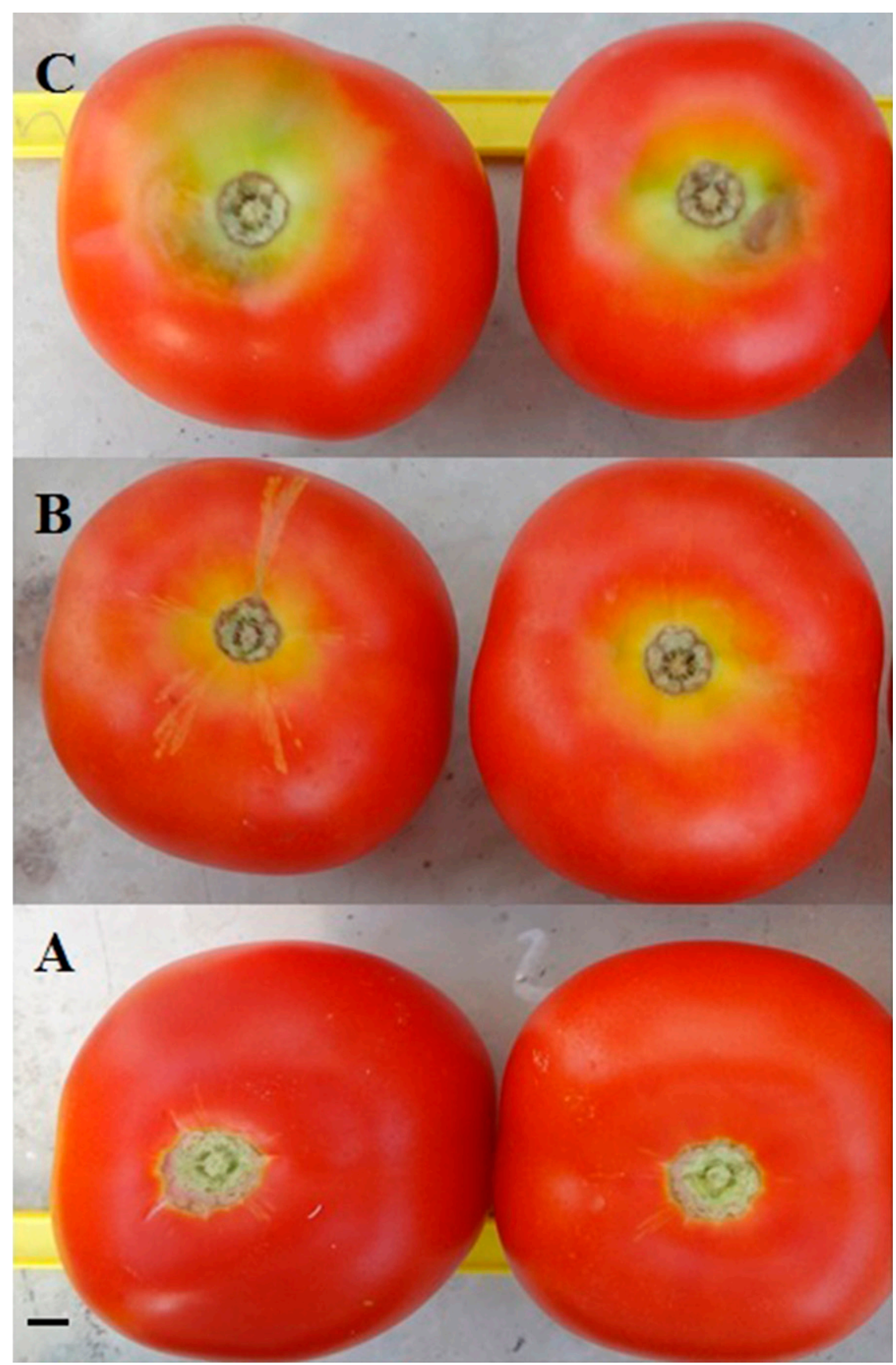

Fig. 1. Cadmium toxicity symptoms in tomato fruits: (A) Control, (B) $25 \mu \mathrm{M} \mathrm{Cd}$, and (C) $50 \mu \mathrm{M} \mathrm{Cd}$. Bar $=8 \mathrm{~mm}$.

observed in fruits from Ikram/Maxifort and especially Ikram/Black Beauty grafting combination.

Fruit yield and biomass production. Tomato fruit yield of all grafted and nongrafted plants decreased in response to $\mathrm{Cd}$ concentration in nutrient solution; the decrease in yield was due to both the reduced fruit number and mean fruit weight caused by $\mathrm{Cd}$ treatments (Table 1). Compared with control $(3.37 \mathrm{~kg} / \mathrm{plant})$, mean fruit yield reduced to 2.77 and $2.51 \mathrm{~kg} /$ plant at 25 and $50 \mu \mathrm{M} \mathrm{Cd}$ level, respectively. Regardless of $\mathrm{Cd}$ level, the fruit yield of different grafting combinations was in the following order: Ikram/ Maxifort > Ikram/Unifort > Ikram/Ikram > nongrafted Ikram $>$ Ikram/Black Beauty as scion, measured below and above the graft union point, respectively, at the termination of experiment. The stem girth of rootstock decreased from 12.6 to 11.0 and $10.5 \mathrm{~mm}$ and of scion from 12.5 to 11.7 and $9.90 \mathrm{~mm}$ from control to 25 and $50 \mu \mathrm{M} \mathrm{Cd}$ levels, respectively. However, grafting combination had no significant effects on stem girth on either side of graft union, which varied from 11.0 to $12.1 \mathrm{~mm}$ and 11.0 to $12.2 \mathrm{~mm}$ for rootstock and scion stem girth, respectively (data not shown).

Mean fruit SI and $\mathrm{pH}$ decreased, but similarly at both $\mathrm{Cd}$ levels (25 and $50 \mu \mathrm{M}$ Cd), whereas fruit DM and TSS content were increased at only $50 \mu \mathrm{M} \mathrm{Cd}$, while TA increased, similarly at both $\mathrm{Cd}$ levels. Fruit firmness also increased in response to $\mathrm{Cd}$ level (Table 2). Averaged over Cd levels, measure of highest DM and TSS content was recorded in Black Beauty-grafted plants, with no statistical difference to other grafting treatments, except Maxifort-grafted plants, which was observed with lowest DM and TSS contents. Moreover, the fruit color indicators $\left(\mathrm{L}^{*}, \mathrm{a}^{*}\right.$, and $\left.\mathrm{b}^{*}\right)$ were significantly affected, but similarly for the two Cd levels (Table 2). The tomato fruit of Ikram/Black Beauty was characterized by higher redness (higher $\mathrm{a}^{*}$ ) and brightness (lower $\mathrm{L}^{*}$ ) as compared with the other grafting combinations (Table 2).

Chlorophyll fluorescence and leaf pigments. Chlorophyll fluorescence, which represents maximum quantum yield of PSII $\left(\mathrm{F}_{\mathrm{v}} / \mathrm{F}_{\mathrm{m}}\right)$, and leaf pigments chlorophyll (Chl a, Chl b, and $\mathrm{Chl} \mathrm{a}+\mathrm{b}$ ) and total carotenoid contents significantly decreased in concentrationdependent manner of $\mathrm{Cd}$ in nutrient solution


$\mathrm{Chl} \mathrm{a}+\mathrm{b}$ contents were distinctly higher in Ikram/Maxifort combination, whereas these $\left(\mathrm{F}_{\mathrm{v}} / \mathrm{F}_{\mathrm{m}}\right.$ and chlorophyll, especially $\mathrm{Chl}$ a content) were recorded lowest in Ikram/Black Beauty plants, regardless of Cd level (Table 3 ). Total carotenoid content was similar among all the grafting combinations, except Ikram/ Black Beauty combination, which showed significantly lower value than others (Table 3 ).

Cadmium uptake and distribution. Cadmium content in tomato plant parts (roots, leaves, and fruits) increased in response to $\mathrm{Cd}$ concentration in nutrient solution (Table 4). The distribution of $\mathrm{Cd}$ within the plant was in order of roots $>$ leaves $>$ fruits. The significantly lower root $\mathrm{Cd}$ content was recorded in Ikram/Black Beauty or Ikram/Unifort combination, whereas higher but similar $\mathrm{Cd}$ content was in Ikram/Maxifort, nongrafted or self-grafted plants. However, the situation of $\mathrm{Cd}$ accumulation in aerial plant parts was apparently different to that was observed in roots in response to grafting. There was marked effect of grafting incision as such on Cd transfer from root to shoot, especially to the leaf as indicated by reduced level of $\mathrm{Cd}$ $(10 \%)$ in leaves, which is main site for important physiological activities, of selfgrafted plants in comparison with nongrafted ones, but the difference in $\mathrm{Cd}$ content among these two was not clear in fruit (Table 5). Higher $\mathrm{Cd}$ accumulation in aerial plant parts 
Table 1. Mean effects of cadmium (Cd) concentration and grafting combination on yield, fruit number and mean weight, shoot and root dry weight, and final leaf area (LA) of tomato plants.

\begin{tabular}{|c|c|c|c|c|c|c|}
\hline \multirow[b]{2}{*}{ Treatments } & \multirow[b]{2}{*}{ Fruit yield (kg/plant) } & \multirow[b]{2}{*}{ Fruit number (per plant) } & \multirow{2}{*}{$\frac{\text { Fruit mean wt }}{(\mathrm{g} / \text { fruit })}$} & Shoot & Root & \multirow{2}{*}{$\frac{\text { LA }}{\left(\mathrm{m}^{2} / \text { plant }\right)}$} \\
\hline & & & & \multicolumn{2}{|c|}{ Dry weight (g/plant) } & \\
\hline Cd level $(\mu \mathrm{M})$ & & & & & & \\
\hline 0 & $3.37 \mathrm{a}$ & $38.7 \mathrm{a}$ & $93.7 \mathrm{a}$ & $210.4 \mathrm{a}$ & $19.2 \mathrm{a}$ & $2.36 \mathrm{a}$ \\
\hline 25 & $2.77 \mathrm{~b}$ & $32.6 \mathrm{~b}$ & $87.8 \mathrm{~b}$ & $154.7 \mathrm{~b}$ & $15.5 \mathrm{~b}$ & $1.78 \mathrm{~b}$ \\
\hline 50 & $2.51 \mathrm{c}$ & $29.8 \mathrm{c}$ & $85.6 \mathrm{~b}$ & $136.3 \mathrm{c}$ & $13.6 \mathrm{c}$ & $1.62 \mathrm{c}$ \\
\hline \multicolumn{7}{|l|}{ Graft combination $(\mathrm{G})$} \\
\hline Ikram & $2.87 \mathrm{bc}$ & $33.96 \mathrm{ab}$ & $88.6 \mathrm{~b}$ & $163.7 \mathrm{~b}$ & $15.2 \mathrm{~b}$ & $1.87 \mathrm{c}$ \\
\hline Ikram/Ikram & $2.94 \mathrm{~b}$ & $34.04 \mathrm{a}$ & $90.7 \mathrm{~b}$ & $170.4 \mathrm{~b}$ & $15.7 \mathrm{~b}$ & $1.92 \mathrm{bc}$ \\
\hline Ikram/Black Beauty & $2.19 \mathrm{c}$ & $32.48 \mathrm{~b}$ & $70.3 \mathrm{c}$ & $147.7 \mathrm{c}$ & $16.3 \mathrm{ab}$ & $1.69 \mathrm{~d}$ \\
\hline Ikram/Unifort & $3.09 \mathrm{ab}$ & $34.08 \mathrm{a}$ & $93.1 \mathrm{~b}$ & $173.0 \mathrm{ab}$ & $16.0 \mathrm{ab}$ & $2.00 \mathrm{ab}$ \\
\hline Ikram/Maxifort & $3.32 \mathrm{a}$ & $33.89 \mathrm{ab}$ & $102.4 \mathrm{a}$ & $182.8 \mathrm{a}$ & $17.1 \mathrm{a}$ & $2.12 \mathrm{a}$ \\
\hline \multicolumn{7}{|l|}{ Significance } \\
\hline $\mathrm{Cd}$ & $* * *$ & $* * *$ & $* * *$ & $* * *$ & $* * *$ & $* * *$ \\
\hline G & $* * *$ & $*$ & $* * *$ & $* * *$ & * & $* * *$ \\
\hline $\mathrm{Cd} \times \mathrm{G}$ & NS & NS & NS & NS & NS & NS \\
\hline
\end{tabular}

Values are the means of three replicate samples.

Means within columns separated using Duncan's multiple range test $P=0.05$.

Ns, ***** Nonsignificant or significant at $P<0.05$ or 0.001 , respectively.

Table 2. Mean effects of cadmium (Cd) concentration and grafting combination on fruit shape index (SI), firmness, dry matter (DM), total soluble solids (TSS) content, juice $\mathrm{pH}$, titratable acidity (TA), and Hunter color values $\left(\mathrm{L}^{*}, \mathrm{a}^{*}\right.$, and $\left.\mathrm{b}^{*}\right)$ of tomato fruits.

\begin{tabular}{|c|c|c|c|c|c|c|c|c|c|}
\hline Treatment & SI & Firmness $\left(\mathrm{N} \cdot \mathrm{cm}^{-2}\right)$ & $\mathrm{DM}(\%)$ & TSS $\left({ }^{\circ}\right.$ Brix $)$ & $\mathrm{pH}$ & TA (\%) & $\mathrm{L}^{*}$ & $a^{*}$ & $\mathrm{~b}^{*}$ \\
\hline \multicolumn{10}{|l|}{ Cd level $(\mu \mathrm{M})$} \\
\hline 25 & $1.20 \mathrm{~b}$ & $2.56 \mathrm{~b}$ & $6.11 \mathrm{ab}$ & $5.57 \mathrm{~b}$ & $4.21 \mathrm{~b}$ & $0.34 \mathrm{a}$ & $37.89 \mathrm{a}$ & $29.54 \mathrm{~b}$ & $29.41 \mathrm{a}$ \\
\hline 50 & $1.22 \mathrm{~b}$ & $2.76 \mathrm{a}$ & $6.26 \mathrm{a}$ & $5.86 \mathrm{a}$ & $4.16 \mathrm{~b}$ & $0.35 \mathrm{a}$ & $38.23 \mathrm{a}$ & $29.07 \mathrm{~b}$ & $30.12 \mathrm{a}$ \\
\hline Ikram & 1.21 & 2.56 & $6.08 \mathrm{ab}$ & $5.56 \mathrm{~b}$ & 4.22 & 0.31 & $37.6 \mathrm{ab}$ & $29.5 \mathrm{~b}$ & 29.1 \\
\hline Ikram/Ikram & 1.23 & 2.55 & $6.11 \mathrm{ab}$ & $5.61 \mathrm{~b}$ & 4.26 & 0.30 & $37.5 \mathrm{ab}$ & $29.1 \mathrm{~b}$ & 28.6 \\
\hline Ikram/Black Beauty & 1.20 & 2.50 & $6.29 \mathrm{a}$ & $5.84 \mathrm{a}$ & 4.20 & 0.33 & $37.0 \mathrm{~b}$ & $31.4 \mathrm{a}$ & 29.9 \\
\hline \multicolumn{10}{|l|}{ Significance } \\
\hline $\mathrm{Cd}$ & $* * *$ & $* * *$ & ** & $* * *$ & *** & $* * *$ & $* * *$ & $*$ & $* * *$ \\
\hline G & NS & NS & * & * & NS & NS & * & * & NS \\
\hline $\mathrm{Cd} \times \mathrm{G}$ & NS & NS & NS & NS & NS & NS & NS & NS & NS \\
\hline
\end{tabular}

Values are the means of three replicate samples.

Means within columns separated using Duncan's multiple range test $P=0.05$.

Ns, * **, *** Nonsignificant or significant at $P<0.05,0.01$, or 0.001 , respectively.

Table 3. Mean effects of cadmium (Cd) concentration and grafting combination on SPAD index, maximum quantum use efficiency of PSII (Fv/Fm), leaf chlorophyll (Chl a, Chl b, Chl a $+\mathrm{b}$ ), and total carotenoids of tomato plants.

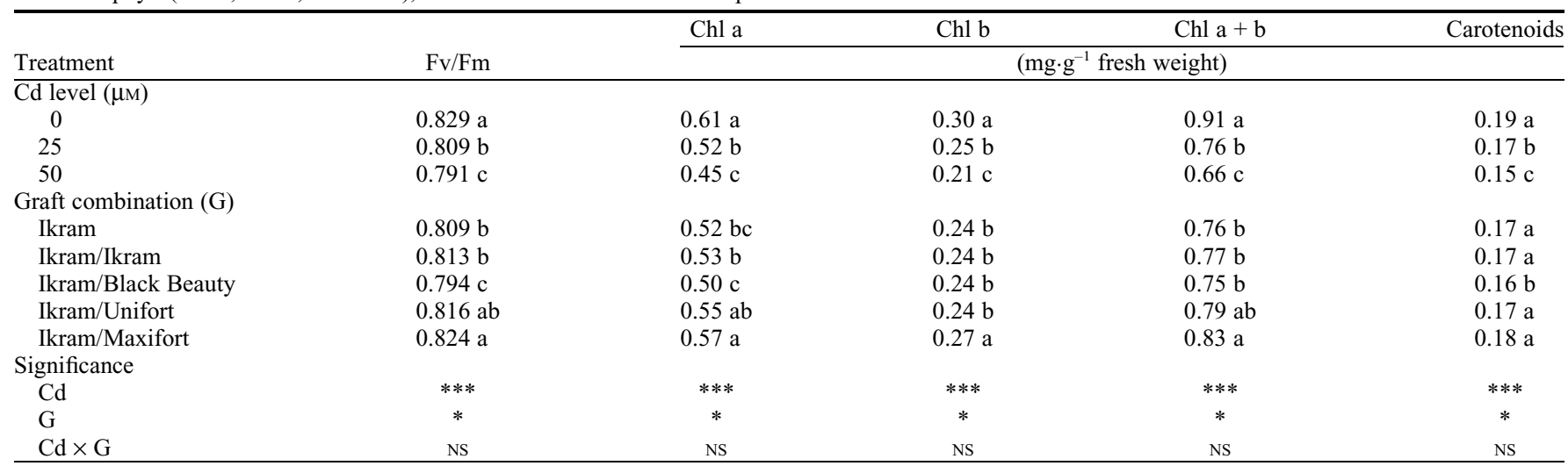

Values are the means of three replicate samples.

Means within columns separated using Duncan's multiple range test $P=0.05$.

Ns, * ,*** Nonsignificant or significant at $P<0.05$ or 0.001 , respectively.

observed in nongrafted plants followed by Unifort-grafted plants. However, significantly, lower Cd content in leaves and fruits was detected in Ikram/Black Beauty followed by Ikram/Maxifort plants, in comparison with nongrafted or self-grafted plants and Ikram/Unifort combination (Table 5). Moreover, the detected levels of Cd content in fruit of different grafting combinations were in corresponding to the observed fruit toxicity symptoms in respective plants. Conversely, compared with nongrafted plants, the mean reduction in Cd contents in Ikram/ Black Beauty and Ikram/Maxifort plants were $23 \%, 17 \%$ and $39 \%, 23 \%$ in leaves and fruits, respectively (Table 4).

Mineral composition and partitioning. Under Cd stress, the content of $\mathrm{N}$ significantly increased in roots but it decreased in leaves, while it remained unaffected in fruits as compared with control $(0 \mu \mathrm{M} C d)$. Nongrafted and self-grafted plants markedly had higher $\mathrm{N}$ in their roots, especially under control than the grafted plants (data not shown). Leaf and fruit $\mathrm{N}$ did not differ among grafting combinations (Table 5). Root P content decreased only at $25 \mu \mathrm{M} \mathrm{Cd}$, contrarily, leaf P content increased 
similarly at both Cd levels, whereas in fruits it decreased only at higher Cd level $(50 \mu \mathrm{M} \mathrm{Cd})$. The content of $\mathrm{P}$ in roots and leaves was found lower in Ikram/Black Beauty and Ikram/ Unifort combination, whereas the highest $\mathrm{P}$ was found in nongrafted plants, though was similar to the others (Table 5). Root $\mathrm{K}$ content was unaffected by either $\mathrm{Cd}$ or grafting treatments. Compared with control, the contents of $\mathrm{K}$ in fruits significantly increased only at $25 \mu \mathrm{M} \mathrm{Cd}$, whereas it decreased in leaves but only at $50 \mu \mathrm{M} \mathrm{Cd}$. Grafting had significant effects on $\mathrm{K}$ content in leaves with highest value in Ikram/Black Beauty followed by Ikram/Unifort combination, while the lowest $\mathrm{K}$ was in nongrafted plants (Table 5). Roots' and leaves' $\mathrm{Ca}$ decreased with no difference in their contents at 25 and $50 \mu \mathrm{M}$ $\mathrm{Cd}$ supply, whereas fruit $\mathrm{Ca}$ was decreased at only higher Cd level (Table 5). However, grafted plants onto Maxifort or Unifort rootstocks had significantly higher level of $\mathrm{Ca}$ in their leaves, fruits, and roots compared with

Table 4. Mean effects of cadmium (Cd) concentration and grafting combination on $\mathrm{Cd}$ distribution in leaf, stem, fruit, and root of tomato plants.

\begin{tabular}{lcrr}
\hline & \multicolumn{1}{c}{ Leaf } & \multicolumn{1}{c}{ Fruit } & Root \\
\cline { 2 - 4 } Cd treatment & \multicolumn{3}{c}{$\left(\mathrm{mg} \cdot \mathrm{kg}^{-1}\right.$ dry weight $)$} \\
\hline Cd level $(\mu \mathrm{M})$ & & & \\
0 & $0.20 \mathrm{c}$ & $0.02 \mathrm{c}$ & $0.2 \mathrm{c}$ \\
25 & $119.5 \mathrm{~b}$ & $6.13 \mathrm{~b}$ & $525.1 \mathrm{~b}$ \\
50 & $225.0 \mathrm{a}$ & $7.96 \mathrm{a}$ & $780.0 \mathrm{a}$ \\
Graft combination $(\mathrm{G})$ & & & \\
Ikram & $131.3 \mathrm{a}$ & $5.51 \mathrm{a}$ & $519.7 \mathrm{a}$ \\
Ikram/Ikram & $118.3 \mathrm{~b}$ & $5.04 \mathrm{a}$ & $511.8 \mathrm{a}$ \\
Ikram/Black Beauty & $100.9 \mathrm{c}$ & $3.35 \mathrm{c}$ & $267.4 \mathrm{~b}$ \\
Ikram/Unifort & $115.1 \mathrm{~b}$ & $5.36 \mathrm{a}$ & $327.3 \mathrm{~b}$ \\
Ikram/Maxifort & $109.0 \mathrm{bc}$ & $4.25 \mathrm{~b}$ & $549.4 \mathrm{a}$ \\
Significance & & & \\
Cd & $* * *$ & $* * *$ & $* * *$ \\
G & $*$ & $* * *$ & $* * *$ \\
Cd $\times \mathrm{G}$ & $\mathrm{NS}$ & $* * *$ & $* * *$ \\
\hline $\mathrm{Val}$
\end{tabular}

Values are the means of three replicate samples. Means within columns separated using Duncan's multiple range test $P=0.05$.

Ns, ${ }^{*}, * * *$ Nonsignificant or significant at $P<0.05$ or 0.001 , respectively. nongrafted or self-grafted plants for leaves $\mathrm{Ca}$ and Ikram/Black Beauty for fruits and roots $\mathrm{Ca}$ content (Table 5). The $\mathrm{Mg}$ content in leaves was similarly decreased at both 25 and $50 \mu \mathrm{M}$ $\mathrm{Cd}$ level, whereas in fruits $\mathrm{Mg}$ decreased at only higher $\mathrm{Cd}$ level. The $\mathrm{Mg}$ content in leaves was significantly higher in Ikram/Maxifort or Ikram/Unifort than the other grafting combinations (Table 5).

As presented in Table 6, the contents of micronutrient elements like $\mathrm{Fe}, \mathrm{Zn}$, and $\mathrm{Cu}$ significantly increased in roots of plants supplied with $\mathrm{Cd}$, whereas root $\mathrm{Mn}$ content decreased. The contents of $\mathrm{Fe}, \mathrm{Mn}$, and $\mathrm{Cu}$ in leaves decreased with increase of Cd stress, while $\mathrm{Zn}$ content decreased only at higher $\mathrm{Cd}$ level. In fruits, the contents of $\mathrm{Fe}, \mathrm{Zn}$, and $\mathrm{Cu}$ significantly decreased only at higher $\mathrm{Cd}$ supply condition $(50 \mu \mathrm{M})$. The Mn contents in fruits decreased at only $25 \mu \mathrm{M} \mathrm{Cd}$. (Table 6). Concerning the grafting combination, the contents of $\mathrm{Fe}$ and $\mathrm{Mn}$ were significantly higher in Ikram/Maxifort or Ikram/Unifort as compared with other grafting combinations, whereas roots' $\mathrm{Zn}$ content was significantly higher in nongrafted or self-grafted tomato and roots' $\mathrm{Cu}$ in Ikram/Black Beauty combination (Table 6). The $\mathrm{Mn}$ and $\mathrm{Cu}$ contents significantly changed only in fruits, where Mn content was higher in Ikram/Maxifort and $\mathrm{Cu}$ content was lower in Ikram/Black Beauty than in the other grafting combinations (Table 6). The root B content increased under Cd stress, which was similar for both $\mathrm{Cd}$ levels, while no clear effect of $\mathrm{Cd}$ was observed on either leaf or fruit B contents. There was no significant effect of grafting combination on B content in any of the analyzed plant parts (Table 6).

\section{Discussion}

Plant growth, fruit yield, and quality. A general response of $\mathrm{Cd}$ toxicity in plants has been the inhibition and reduction of shoot and root biomass production (Hayat et al., 2012; López-Millán et al., 2009) and yield reduction in many crops (Irfan et al., 2013; Yang et al., 1998), including tomato (Khan and
Khan, 1983; Moral et al., 1994). In the present study, a significant depression in yield, shoot and root biomass, and LA was observed; however, the effects varied in response to $\mathrm{Cd}$ concentration in the nutrient solution (Table 1). The decrease in fruit yield was directly related to the decrease in fruit number and mean fruit weight (Table 1). This result is supported by the findings of Shekar et al. (2011), who observed the reduction in flower and fruit number and mean fruit weight of tomato in response to increased $\mathrm{Cd}$ level in soil. Moreover, Cd toxicity reduced LA in tomato plants (Djebali et al., 2005, 2010; Hayat et al., 2012), this was reportedly due to reduction in leaf expansion as a result of reduced cell size and small intercellular spaces (Djebali et al., 2005). Plants exposed to highest Cd level $(50 \mu \mathrm{M}$ Cd) exhibited leaf chlorosis symptoms, especially on older leaves, as also reported in earlier studies on tomato in response to $\mathrm{Cd}$ stress (Hasan et al., 2011; López-Millán et al., 2009). The high mobile nature of $\mathrm{Cd}$ in plants (Gallego et al., 2012) explains the appeared toxicity symptoms on older leaves. In addition to leaf chlorosis, we observed a typical disorder in fruit in this study as stem-end-fruit yellowing (Fig. 1). Although vegetable crop productivity reduced under abiotic stresses, the enhancement in some quality attributes was reported to occur (Rouphael et al., 2010, 2012). In fact, fruit quality parameters such as DM, TSS, TA, and firmness increased in presence of $\mathrm{Cd}$ in nutrient solution; this was due to reduced accumulation of water in the fruits, thus resulting in enhanced concentration of some fruit solids (e.g., sugars and acids), as reported under saline stress (Flores et al., 2010) while others were adversely affected like fruit SI, $\mathrm{pH}$, and fruit color factors, described by decreased fruit redness $\left(\mathrm{a}^{*}\right)$ and increased lightness $\left(\mathrm{L}^{*}\right)$ and yellowness $\left(\mathrm{b}^{*}\right)$ (Table 2$)$. Based on the fruit quality parameters, Ikram/ Black Beauty combination has shown to have better fruit quality as compared with other grafting combinations (Table 2). Nevertheless, excess level of $\mathrm{Cd}$ in the growth medium

Table 5. Mean effects of cadmium $(\mathrm{Cd})$ concentration and grafting combination on macronutrient concentration in leaves, stems, fruits, and roots of tomato plants.

\begin{tabular}{|c|c|c|c|c|c|c|c|c|c|c|c|c|c|c|c|}
\hline \multirow{2}{*}{ Treatment } & \multicolumn{15}{|c|}{ Macronutrients $\left(\mathrm{g} \cdot \mathrm{kg}^{-1}\right.$ dry weight $)$} \\
\hline & \multicolumn{3}{|c|}{$\mathrm{N}$} & \multicolumn{3}{|c|}{$\mathrm{P}$} & \multicolumn{3}{|c|}{$\mathrm{K}$} & \multicolumn{3}{|c|}{$\mathrm{Ca}$} & \multicolumn{3}{|c|}{$\mathrm{Mg}$} \\
\hline \multicolumn{16}{|l|}{$\overline{\text { Cd level }(\mu \mathrm{M})}$} \\
\hline 25 & $30.3 \mathrm{~b}$ & 24.9 & $30.0 \mathrm{a}$ & $7.0 \mathrm{a}$ & $5.5 \mathrm{ab}$ & $3.7 \mathrm{~b}$ & $34.3 \mathrm{a}$ & $30.4 \mathrm{a}$ & 14.4 & $34.1 \mathrm{~b}$ & $1.2 \mathrm{a}$ & $8.7 \mathrm{~b}$ & $5.0 \mathrm{~b}$ & $2.0 \mathrm{a}$ & 1.7 \\
\hline 50 & $30.1 \mathrm{~b}$ & 24.9 & $31.2 \mathrm{a}$ & $7.2 \mathrm{a}$ & $4.5 \mathrm{~b}$ & $4.5 \mathrm{a}$ & $29.8 \mathrm{~b}$ & $20.6 \mathrm{~b}$ & 16.6 & $34.6 \mathrm{~b}$ & $0.8 \mathrm{~b}$ & $8.3 \mathrm{~b}$ & $4.9 \mathrm{~b}$ & $1.3 \mathrm{~b}$ & 1.8 \\
\hline \multicolumn{16}{|l|}{ Graft combination (G) } \\
\hline Ikram & 30.35 & 25.03 & $31.5 \mathrm{a}$ & $7.74 \mathrm{a}$ & 5.27 & $4.8 \mathrm{a}$ & $30.04 \mathrm{c}$ & 24.10 & 16.9 & $31.83 \mathrm{~b}$ & $1.03 \mathrm{ab}$ & $9.6 \mathrm{ab}$ & $5.66 \mathrm{~b}$ & 1.53 & 1.8 \\
\hline Ikram/Unifort & 32.27 & 26.63 & $27.5 \mathrm{~b}$ & $6.76 \mathrm{~b}$ & 5.57 & $4.0 \mathrm{~b}$ & $34.40 \mathrm{ab}$ & 24.50 & 16.2 & $36.34 \mathrm{ab}$ & $1.17 \mathrm{a}$ & $10.1 \mathrm{a}$ & $6.03 \mathrm{ab}$ & 1.57 & 1.8 \\
\hline Ikram/Maxifort & 31.30 & 24.90 & $27.8 \mathrm{~b}$ & $6.95 \mathrm{ab}$ & 5.53 & $4.1 \mathrm{ab}$ & $32.79 \mathrm{bc}$ & 24.67 & 15.1 & $38.13 \mathrm{a}$ & $1.27 \mathrm{a}$ & $9.3 \mathrm{ab}$ & $6.29 \mathrm{a}$ & 1.67 & 1.8 \\
\hline \multicolumn{16}{|l|}{ Significance } \\
\hline $\mathrm{Cd}$ & $*$ & NS & $* *$ & $* *$ & $* * *$ & $* *$ & * & $* * *$ & NS & * & $* * *$ & $* *$ & $* * *$ & $* * *$ & NS \\
\hline G & NS & NS & * & $* * *$ & NS & $* *$ & $* * *$ & NS & NS & $*$ & * & * & * & NS & NS \\
\hline $\mathrm{Cd} \times \mathrm{G}$ & NS & NS & * & NS & NS & NS & NS & NS & NS & NS & NS & NS & NS & NS & NS \\
\hline
\end{tabular}

Values are the means of three replicate samples.

Means within columns separated using Duncan's multiple range test $P=0.05$.

Ns, ${ }^{*}, * * * * *$ Nonsignificant or significant at $P<0.05,0.01$, or 0.001 , respectively. 
Table 6. Mean effects of solution cadmium concentration and grafting combination on micronutrient composition of leaves, fruits, and roots of tomato plants.

\begin{tabular}{|c|c|c|c|c|c|c|c|c|c|c|c|c|c|c|c|}
\hline \multirow{2}{*}{ Treatment } & \multicolumn{15}{|c|}{ Micronutrients (mg. $\mathrm{kg}^{-1}$ dry weight) } \\
\hline & \multicolumn{3}{|c|}{$\mathrm{Fe}$} & \multicolumn{3}{|c|}{$\mathrm{Zn}$} & \multicolumn{3}{|c|}{$\mathrm{Mn}$} & \multicolumn{3}{|c|}{$\mathrm{Cu}$} & \multicolumn{3}{|c|}{ B } \\
\hline \multicolumn{16}{|l|}{ Cadmium level $(\mathrm{Cd}, \mu \mathrm{M})$} \\
\hline 25 & $35.2 \mathrm{~b}$ & $23.2 \mathrm{a}$ & $479.3 \mathrm{a}$ & $29.7 \mathrm{a}$ & $14.1 \mathrm{a}$ & $57.3 \mathrm{a}$ & $184.2 \mathrm{~b}$ & $19.1 \mathrm{a}$ & $64.1 \mathrm{~b}$ & $2.21 \mathrm{~b}$ & $4.17 \mathrm{a}$ & $25.5 \mathrm{~b}$ & 60.4 & $9.11 \mathrm{a}$ & $11.3 \mathrm{a}$ \\
\hline 50 & $30.4 \mathrm{c}$ & $12.4 \mathrm{~b}$ & $466.3 \mathrm{a}$ & $24.3 \mathrm{~b}$ & $10.2 \mathrm{~b}$ & $56.3 \mathrm{a}$ & $168.2 \mathrm{c}$ & $10.4 \mathrm{~b}$ & $43.1 \mathrm{c}$ & $1.24 \mathrm{c}$ & $2.39 \mathrm{~b}$ & $35.2 \mathrm{a}$ & 65.0 & $8.32 \mathrm{~b}$ & $11.4 \mathrm{a}$ \\
\hline \multicolumn{16}{|l|}{ Graft combination (G) } \\
\hline Ikram & $35.2 \mathrm{~b}$ & 19.0 & $401.9 \mathrm{~b}$ & 29.2 & 12.0 & $56.1 \mathrm{a}$ & $178.7 \mathrm{bc}$ & $12.7 \mathrm{~b}$ & $68.3 \mathrm{~b}$ & $1.91 \mathrm{a}$ & $4.14 \mathrm{a}$ & $24.9 \mathrm{bc}$ & 59.0 & 8.21 & 12.1 \\
\hline Ikram/Unifort & $38.8 \mathrm{ab}$ & 20.2 & $373.9 \mathrm{~b}$ & 30.2 & 11.8 & $44.3 \mathrm{~b}$ & $190.1 \mathrm{a}$ & $13.4 \mathrm{~b}$ & $57.8 \mathrm{c}$ & $2.11 \mathrm{a}$ & $4.21 \mathrm{a}$ & $23.3 \mathrm{bc}$ & 64.4 & 9.20 & 10.9 \\
\hline Ikram/Maxifort & $40.1 \mathrm{a}$ & 22.4 & $524.1 \mathrm{a}$ & 28.8 & 12.4 & $46.4 \mathrm{~b}$ & $202.9 \mathrm{a}$ & $15.7 \mathrm{a}$ & $80.0 \mathrm{a}$ & $2.35 \mathrm{a}$ & $3.38 \mathrm{a}$ & $26.7 \mathrm{ab}$ & 60.2 & 9.22 & 11.3 \\
\hline \multicolumn{16}{|l|}{ Significance } \\
\hline $\mathrm{Cd}$ & $* * *$ & $* * *$ & $* * *$ & ** & $* * *$ & $* * *$ & * & $* * *$ & $* * *$ & $* * *$ & $* * *$ & $* * *$ & NS & $* *$ & * \\
\hline G & $* *$ & NS & $* * *$ & NS & NS & $* * *$ & $* *$ & $*$ & $* * *$ & * & $* *$ & $* *$ & NS & NS & NS \\
\hline $\mathrm{Cd} \times \mathrm{G}$ & NS & NS & $*$ & NS & NS & $*$ & NS & NS & $*$ & NS & NS & $* * *$ & NS & NS & NS \\
\hline
\end{tabular}

Values are the means of three replicate samples.

Means within columns separated using Duncan's multiple range test $P=0.05$.

Ns, $*, * *, * * *$ Nonsignificant or significant at $P<0.05,0.01$, or 0.001 , respectively.

can lead to an increase of Cd content in fruits, which represent a serious risk for human health.

Recent studies have shown that rootstockgrafted plants had lower concentration of $\mathrm{Cd}$ in shoots and fruits of eggplants (Arao et al., 2008; Mori et al., 2009), melon (Edelstein and Ben-Hur, 2012), and cucumber (Savvas et al., 2013) as compared with nongrafted plants. Moreover, working with melon and cucumber under toxic concentration of $\mathrm{B}$ and $\mathrm{Cu}$, Edelstein et al. (2007) and Rouphael et al. (2008c), respectively, found that the better plant growth and fruit yield in these crops were observed when plants were grafted onto vigorous rootstock of 'pumpkin' as compared with nongrafted plants. The lower level of toxic metal elements (Edelstein et al., 2007) along with better plant physiological functioning associated with the better availability of nutrients (Rouphael et al., 2008c) in rootstock-grafted plants ascribed to the overall better performance of grafted plants. Similarly, in the current study, fruit yield and plant biomass production were higher in grafted plants, especially onto tomato rootstocks Maxifort or Unifort as compared with other grafting combinations. The response of grafting combination in relation to yield and biomass production was partly related to the toxic metal concentration in leaves with exception of Ikram/Black Beauty combination, which was most seriously affected even with having lowest level of $\mathrm{Cd}$ in all analyzed plant parts. In spite of lower level of Cd in Ikram/Black Beauty plants, the contents of certain essential elements $(\mathrm{P}, \mathrm{Mg}, \mathrm{Mn}, \mathrm{Cu}$, and $\mathrm{Fe}$ ) in leaves were also lower and showing severe leaf chlorosis symptoms. The nutritional deficiency in Ikram/Black Beauty plants might have led to the nutrient imbalance and physiological disorders, thereby poor plant performance (Dong et al., 2006), possibly due to some incompatibility reaction between scion cv. Ikram and Black Beauty rootstock. Davis et al. (2008) reported that rootstock/ scion incompatibility induced under or overgrowth of scion that could result in decreased water and nutrient flow through the graft union and eventually led sometimes to wilting of the plant. However, unlike plant growth and yield, fruits obtained from Ikram/Black Beauty were comparatively better than other grafting combinations as evident by higher DM and TSS content and better fruit color (lower fruit lightness, $\mathrm{L}^{*}$ and higher redness, $\mathrm{a}^{*}$ ), associated with least $\mathrm{Cd}$ toxicity symptoms (stemend yellowing); these could be directly related to lowest detected $\mathrm{Cd}$ contents in the fruits. Besides Ikram/Black Beauty, fruits from Ikram/Maxifort showed intermediate Cd content (Table 5), thus lower appearance of toxicity symptoms on fruits. However, further study is needed to elucidate the relation of $\mathrm{Cd}$ ion localization and damage to specific part or tissues of fruit.

Chlorophyll fluorescence and leaf pigments. The higher yield and biomass production in plants grafted onto Maxifort or Unifort could be in part due to the maintenance of higher maximum quantum yield of PSII $\left(\mathrm{F}_{\mathrm{v}} / \mathrm{F}_{\mathrm{m}}\right)$, compared with other grafting combinations. This higher $F_{v} / F_{m}$ suggests that grafted plants onto appropriate rootstocks can delay photoinhibition under heavy metal stress, as has been also reported under other type of stresses (Colla et al., 2013; He et al., 2009). Moreover, the Maxifort- or Unifort-grafted plants could have maintained the higher chlorophyll (chl a, chl $b$, and chl $a+b)$ content than the other grafting combinations (Table 3). Similar response of grafting was observed for Cu toxicity (Rouphael et al., 2008c) and salinity toxicity (Colla et al., 2013), where chlorophyll content was significantly higher in grafted plant than those of nongrafted ones. The higher activity of PSII together with higher chlorophyll contents in tomato rootstock-grafted plants, especially onto Maxifort ascribed to higher LA and finally the overall biomass production than other grafting combinations.

Cadmium uptake and distribution. The observed high amount of $\mathrm{Cd}$ accumulation in roots ascribed to the metal chelation and sequestration process in roots and the development of extracellular barriers, which restrict the apoplastic movements of $\mathrm{Cd}$ to xylem (Lux et al., 2011). The Cd translocation from root to physiologically active leaf tissue was restricted by grafting as indicated by the observed lower leaf $\mathrm{Cd}$ concentration of self-grafted plants than nongrafted plants, though $\mathrm{Cd}$ concentration was similar in their roots (Table 4). The Black Beauty and Unifort rootstocks displayed better ability to restrict $\mathrm{Cd}$ entry into roots as evident by observed much lower $\mathrm{Cd}$ concentration in their roots as compared with other grafting combinations. Furthermore, the lower $\mathrm{Cd}$ in leaves and fruits of Black Beauty-grafted plants showed limited root-to-shoot Cd transfer, but it was not the case for Unifort-grafted plants, which had higher Cd content in their leaves. Although, Cd concentration in roots of Maxifort-grafted plants was higher, though similar to those of self-grafted plants or nongrafted plants, it was much lower in the leaves and fruits, which indicate the better ability of Maxifort rootstock in limiting rootto-shoot transfer of toxic metal. Plant can deploy different mechanisms to reduce the level of toxic metals in the shoots as suggested by the results of earlier studies (Arao et al., 2008; Mori et al., 2009; Savvas et al., 2013). For example, the lower Cd contents in aerial parts of cucumber plants grafted onto pumpkin rootstock was due to restricted $\mathrm{Cd}$ uptake (Savvas et al., 2013), whereas, it was due to limited root-to-shoot transfer, but not by restricted uptake in eggplant grafted onto S. torvum rootstock (Arao et al., 2008; Mori et al., 2009) compared with nongrafted or self-grafted plants.

Nutrient uptake, translocation, and accumulation. Excess of $\mathrm{Cd}$ in nutrient solution significantly inhibited translocation of $\mathrm{N}$, $\mathrm{K}, \mathrm{Ca}, \mathrm{Mg}, \mathrm{Fe}, \mathrm{Zn}, \mathrm{Mn}$, and $\mathrm{Cu}$ to the leaves. However, there was an increase in uptake of most of these nutrients along with $\mathrm{B}$, except $\mathrm{Mn}$ and $\mathrm{Ca}$, which were decreased in roots and $\mathrm{K}$ and $\mathrm{Mg}$ which remained unaffected as evident by their observed concentrations in roots (Tables 5 and 6). In general, the contents of most of the nutrient elements were decreased in fruit tissues, especially at $50 \mu_{\mathrm{M}} \mathrm{Cd}$ application. Similar differential response in mineral elements uptake by roots and their accumulation 
in leaves have been also observed in previous studies under variable Cd stress (Dong et al., 2006; López-Millán et al., 2009; Sandalio et al., 2001). The change in nutrient uptake is possibly due to affected permeability of plasma membranes by $\mathrm{Cd}$ toxicity (Dong et al., 2006). It has been reported that $\mathrm{Cd}$ interferes mainly with the translocation of most of the micronutrients, especially those having same valences, to the leaves despite of having synergistic effects on their uptake (Sandalio et al., 2001). Higher plant biomass and yield in tomato rootstock-grafted plants (Maxifort or Unifort) under Cd stress could partly be related to better nutritional status, especially of Ca, $\mathrm{Mg}, \mathrm{Fe}, \mathrm{Mn}$, and $\mathrm{Cu}$ (Tables 5 and 6); some of these nutrient elements (e.g., $\mathrm{Fe}, \mathrm{Mn}$, and $\mathrm{Cu}$ ) are important constituents of many enzymes and proteins (Hall, 2002; López-Millán et al., 2009). In contrast, the severe reduction in growth and yield and the appeared phytotoxicity symptoms of Cd stress in plants grafted onto Black Beauty rootstock was mainly ascribed to the reduction of nutrient availability in the leaf tissue $(\mathrm{P}, \mathrm{Mg}$, $\mathrm{Fe}, \mathrm{Mn}$, and $\mathrm{Cu}$, Tables 5 and 6).

\section{Conclusions}

The yield and biomass production decreased in grafted, self-grafted, and nongrafted plants in response to the increase of $\mathrm{Cd}$ concentration in the nutrient solution. However, grafting onto appropriate rootstocks reduced the toxic effects of Cd. Plants grafted onto tomato rootstocks, especially onto Maxifort were able to reduce toxic metal contents in aerial parts while maintaining better nutritional status (i.e., higher $\mathrm{Ca}, \mathrm{Mg}, \mathrm{Fe}, \mathrm{Mn}$, and $\mathrm{Cu}$ ) in leaves and higher chlorophyll content and $\mathrm{F}_{\mathrm{v}} / \mathrm{F}_{\mathrm{m}}$ ratio in comparison with nongrafted or self-grafted and especially those grafted onto Black Beauty rootstock.

\section{Literature Cited}

Abdelmageed, A.H.A. and N. Gruda. 2009. Influence of grafting on growth, development and some physiological parameters of tomatoes under controlled heat stress conditions. Europ. J. Hort. Sci. 74:16-20.

Alexander, P.D., B.J. Alloway, and A.M. Dourado. 2006. Genotypic variations in the accumulation of $\mathrm{Cd}, \mathrm{Cu}, \mathrm{Pb}$ and $\mathrm{Zn}$ exhibited by six common grown vegetables. Environ. Pollut. 144:736-745.

Alybayeva, R.A., S.S. Kenzhebayeva, and S.D. Atabayeva. 2014. Screening of wheat genotypes for metal tolerance breeding and agricultural production. Fifth World Congress on Biotechnology, 25-27 June, 2014, Valencia, Spain.

Arao, T., H. Takeda, and E. Nishihara. 2008. Reduction of cadmium translocation from roots to shoots in eggplant (Solanum melongena) by grafting onto Solanum torvum rootstock. Soil Sci. Plant Nutr. 54:555-559.

Bertoli, A.C., M.G. Cannata, R. Carvalho, A.R.R. Bastos, M.P. Freitas, and A.D.S. Augusto. 2012. Lycopersicon esculentum submitted to Cd-stressful conditions in nutrition solution: Nutrient contents and translocation. Ecotoxicol. Environ. Saf. 86:176-181.

Bremner, J.M. 1965. Total nitrogen, p. 1149-1178. In: C.A. Black, D.D. Evans, I.L. White, I.L.L.E.
Ensminger, and F.E. Clark (eds.). Methods of soil analysis. Agronomy monograph 9, Part 2. Amer. Soc. Agr. Inc., Madison, WI.

Chen, F., F. Wang, G.P. Zhang, and F.B. Wu. 2007. Identification of barley varieties tolerant to cadmium toxicity. Biol. Trace Elem. Res. 121:171179.

Colla, G., Y. Rouphael, M. Cardarelli, O. Temperini, E. Rea, A. Salerno, and F. Pierandrei. 2008. Influence of grafting on yield and fruit quality of pepper (Capsicum annuum L.) grown under greenhouse conditions. Acta Hort. 782:359-363.

Colla, G., Y. Rouphael, M. Cardarelli, A. Salerno, and E. Rea. 2010a. The effectiveness of grafting to improve alkalinity tolerance in watermelon. Environ. Expt. Bot. 68:283-291.

Colla, G., Y. Rouphael, R. Jawad, P. Kumar, E. Rea, and M. Cardarelli. 2013. The effectiveness of grafting to improve $\mathrm{NaCl}$ and $\mathrm{CaCl}_{2}$ tolerance in cucumber. Sci. Hort. 164:380-391.

Colla, G., Y. Rouphael, C. Leopardi, and Z. Bie. $2010 \mathrm{~b}$. Role of grafting in vegetable crops grown under saline conditions. Sci. Hort. 127:147-155.

Colla, G., Y. Rouphael, E. Rea, and M. Cardarelli. 2012. Grafting cucumber plants enhance tolerance to sodium chloride and sulfate salinization. Sci. Hort. 135:177-185.

Crinò, P., C. Lo Bianco, Y. Rouphael, G. Colla, F. Saccardo, and A. Paratore. 2007. Evaluation of rootstock resistance to fusarium wilt and gummy stem blight and effect on yield and quality of a grafted 'Inodorus' melon. HortScience 42: 521-525.

Davis, A.R., C.L. Webber, III, P. Perkins-Veazie, V. Ruso, S.L. Galarza, and Y. Sakata. 2008. A review of production systems on watermelon quality, p. 515-520. In: M. Pitrat (ed.). Cucurbitaceae 2008, Proceedings of the IXth EUCARPIA meeting on genetics and breeding of Cucurbitaceae, May 21-24th, 2008, INRA, Avignon, France.

Djebali, W., H. Hediji, Z. Abbes, Z. Barhoumi, H. Yaakoubi, L.B. Zoghlami, and W. Chaibi. 2010. Aspects on growth and anatomy of internodes and leaves of cadmium-treated Solanum lycopersicum L. plants. J. Biol. Res. Thessalonica 13:75-84.

Djebali, W., M. Zarrouk, R. Brouquisse, S. ElKahoui, F. Limam, M.H. Ghorbel, and W. Chaibi. 2005. Ultrastructure and lipid alterations induced by cadmium in tomato (Lycopersicon esculentum) chloroplast membranes. Plant Biol. 7:258-368.

Dong, J., F. Wu, and G. Zhang. 2006. Influence of cadmium on antioxidant capacity and four microelement concentrations in tomato seedlings (Lycopersicon esculentum). Chemosphere 64: 1659-1666.

Dong, J., W.H. Mao, G.P. Zhang, F.B. Wu, and Y. Cai. 2007. Root secretion and plant tolerance to cadmium toxicity-A review. Plant Soil Environ. 53(5):193-200.

Edelstein, M. and M. Ben-Hur. 2012. Use of grafting to mitigate chemical stresses in vegetables under arid and semiarid conditions, p. 163179. In: J.A. Daniels (ed.). Advances in Environ. Res. Vol. 20. Nova Science Publishers, Inc., New York, NY.

Edelstein, M., M. Ben-Hur, and Z. Plaut. 2007. Grafted melons irrigated with fresh or effluent water tolerate excess boron. J. Amer. Soc. Hort. Sci. 132:484-491.

Fanasca, S., G. Colla, Y. Rouphael, and F. Saccardo. 2006. Evolution of nutritional value of two tomato genotypes grown in soilless culture as affected by cacrocation proportions. HortScience 41:1584 1588 .

Flores, F.B., P. Sanchez-Bel, M.T. Estan, M.M. Martinez-Rodriguez, E. Moyano, B. Morales,
J.F. Campos, J.O. Garcia-Abellán, M.I. Egea, N. Fernández-Garcia, F. Romojaro, and M.C. Bolarín. 2010. The effectiveness of grafting to improve tomato fruit quality. Sci. Hort. 125: 211-217.

Gallego, S.M., L.B. Pena, R.A. Barcia, C.E. Azpilicueta, M.F. Iannone, E.P. Rosales, M.S. Zawoznik, M.D. Groppa, and M.P. Benavides. 2012. Unravelling cadmium toxicity and tolerance in plants: Insight into regulatory mechanisms. Environ. Expt. Bot. 83:33-46.

Groppa, M.D. and M.P. Benavides. 2008. Polyamines and abiotic stress: Recent advances. Amino Acids 34:35-45.

Hall, J.L. 2002. Cellular mechanisms for heavy metal detoxification and tolerance. J. Expt. Bot. $53: 1-11$.

Hasan, S.A., S. Hayat, and A. Ahmad. 2011. Brassinosteroids protect photosynthetic machinery against the cadmium induced oxidative stress in two tomato cultivars. Chemosphere 84:1446-1451.

Hayat, S., M.N. Alyemenia, and S.A. Hasan. 2012. Foliar spray of brassinosteroid enhances yield and quality of Solanum lycopersicum under cadmium stress. Saudi J. Biol. Sci. 19:325-335.

He, Y., Z.J. Zhu, J. Yang, X.L. Ni, and B. Zhu. 2009. Grafting increases the salt tolerance of tomato by improvement of photosynthesis and enhancement of antioxidant enzymes activity. Environ. Expt. Bot. 66:270-278.

Hédiji, H., W. Djebali, C. Cabasson, M. Maucourt, P. Baldet, A. Bertrand, L.B. Zoghlami, C. Deborde, A. Moing, R. Brouquisse, W. Chaibi, and P. Gallusci. 2010. Effects of long-term cadmium exposure on growth and metabolomic profile of tomato plants. Ecotoxicol. Environ. Saf. 73:1965-1974.

Irfan, M., S. Hayat, A. Ahmad, and M.N. Alyemeni. 2013. Soil cadmium enrichment: Allocation and plant physiological manifestations. Saudi J. Biol. Sci. 20:1-10.

Jones, J.B. 1983. A guide for the hydroponic and soilless culture grower. Timber Press, Portland, Orlando.

Karla, Y.P. 1998. Handbook of reference methods for plant analysis, p. 165-170. CRC Press Inc., Boca Raton, FL.

Khan, S. and N.N. Khan. 1983. Influence of lead and cadmium on the growth and nutrient concentration of tomato (Lycopersicum esculentum) and eggplant (Solanum melongena). Plant Soil 74:387-394

Kumar, P., Y. Rouphael, M. Cardarelli, and G. Colla. 2015. Effect of nickel and grafting combination on yield, fruit quality, antioxidative enzyme activities, lipid peroxidation, and mineral composition of tomato. J. Plant Nutr. Soil Sci., doi: 10.1002/jpln.201400651.

Lee, J.M. 1994. Cultivation of grafted vegetables: Current status, grafting methods, and benefits. HortScience 29:235-239.

Lichtenhaler, H.K. and A.R. Wellburn. 1983. Determinations of total carotenoids and chlorophylls $\mathrm{a}$ and $\mathrm{b}$ of leaf extracts in different solvents. Proc. Biochem. Soc. Trans. 603rd meeting, Liverpool. 11:591-592.

López-Millán, A.F., R. Sagardoy, M. Solanas, A. Abadía, and J. Abadía. 2009. Cadmium toxicity in tomato (Lycopersicon esculentum) plants grown in hydroponics. Environ. Expt. Bot. 65:376-385.

Lux, A., M. Martinka, M. Vaculík, and P.J. White. 2011. Root responses to cadmium in the rhizosphere: A review. J. Expt. Bot. 62:21-37.

Maxwell, K. and G.N. Johnson. 2000. Chlorophyll fluorescence-A practical guide. J. Expt. Bot. 51:659-668. 
Moral, R., I. Gomez, J. Navarro-Pedreno, and J. Mataix. 1994. Effects of cadmium on nutrient distribution, yield, and growth of tomato grown in soilless culture. J. Plant Nutr. 17:953-962.

Mori, S., S. Uraguchi, S. Ishikawa, and T. Arao. 2009. Xylem loading process is a critical factor in determining $\mathrm{Cd}$ accumulation in the shoots of Solanum melongena and Solanum torvum. Environ. Expt. Bot. 67:127-132.

Rouphael, Y., M. Cardarelli, A. Bassal, C. Leonardi, F. Giuffrida, and G. Colla. 2012. Vegetable quality as affected by genetic, agronomic and environmental factors. J. Food Agr. Environ. 10:680-688.

Rouphael, Y., M. Cardarelli, G. Colla, and E. Rea. 2008a. Yield, mineral composition, water relations, and water use efficiency of grafted mini-watermelon plants under deficit irrigation. HortScience 43:730-736.

Rouphael, Y., M. Cardarelli, E. Rea, and G. Colla. 2008 b. Grafting of cucumber as a means to minimize copper toxicity. Environ. Expt. Bot. 63:49-58.

Rouphael, Y., M. Cardarelli, E. Rea, and G. Colla. 2008c. The influence of irrigation system and nutrient solution concentration on potted geranium production under various conditions of radiation and temperature. Sci. Hort. 118:328-337.

Rouphael, Y., M. Cardarelli, E. Rea, and G. Colla. 2012. Improving melon and cucumber photosynthetic activity, mineral composition, and growth performance under salinity stress by grafting onto Cucurbita hybrid rootstocks. Photosynthetica 50:180-188.

Rouphael, Y., G. Colla, A. Battistelli, S. Moscatello, S. Proietti, and E. Rea. 2004. Yield, water requirement, nutrient uptake and fruit quality of zucchini squash grown in soil and closed soilless culture. J. Hort. Sci. Biotechnol. 79:423-430.

Rouphael, Y., D. Schwarz, A. Krumbein, and G. Colla. 2010. Impact of grafting on product quality of fruit vegetables. Sci. Hort. 127:172-179.

Sandalio, L.M., H.C. Dalurzo, M. Gómez, M.C. Romero-Puertas, and L.A. del Río. 2001. Cadmium-induced changes in the growth and oxidative metabolism of pea plants. J. Expt. Bot. 52:2115-2126.

Savvas, D., G. Ntatsi, and P. Barouchas. 2013. Impact of grafting and rootstock genotype on cation uptake by cucumber (Cucumis sativus L.) exposed to $\mathrm{Cd}$ or $\mathrm{Ni}$ stress. Sci. Hort. 149:86-96.
Schwarz, D., Y. Rouphael, G. Colla, and J.H. Venema. 2010. Grafting as a tool to improve tolerance of vegetables to abiotic stresses: Thermal stress, water stress and organic pollutants. Sci. Hort. 127:162-171.

Shekar, C.C., D. Sammaiah, M. Rambabuand, and K.J. Reddy. 2011. Effect of cadmium on tomato growth and yield attributes. J. Microbiol. Biotech. Res. 1:109-112.

Tsyganov, V.E., A.A. Belimov, A.Y. Borisov, V.I. Safronova, M. Georgi, K.J. Dietz, and I.A. Tikhonovich. 2007. A chemically induced new pea (Pisum sativum) mutant SGECdt with increased tolerance to, and accumulation of, cadmium. Ann. Bot. 99:227-237.

Xu, J., Y. Zhu, Q. Ge, Y. Li, J. Sun, Y. Zhang, and X. Liu. 2012. Comparative physiological responses of Solanum nigrum and Solanum torvum to cadmium stress. New Phytol. 196:125-138.

Yang, M.G., X.Y. Lin, and X.E. Yang. 1998. Impact of $\mathrm{Cd}$ on growth and nutrient accumulation of different plant species. Chin. J. Appl. Ecol. 19:89-94.

Zhou, W.B. and B.S. Qiu. 2005. Effects of cadmium hyperaccumulation on physiological characteristics of Sedum alfredii Hance (Crassulaceae). Plant Sci. 169:737-745. 